\title{
Parameters of the angle-lift of the front plow for smooth, rowless plowing
}

\author{
Nikolay Aldoshin ${ }^{2}$, Sherzod Kurbanov ${ }^{1 *}$, Akmal Abdullaev ${ }^{3}$, Alham Khujayev ${ }^{3}$ and Dilsabo \\ Choriyeva $^{1}$ \\ ${ }^{1}$ Karshi Engineering Economic Institute, Karshi, Uzbekistan \\ ${ }^{2}$ Moscow Agricultural Academy named after K.A.Timiryazeva, Moscow, Russia \\ ${ }^{3}$ Karshi branch of Tashkent Institute of Irrigation and Agricultural Mechanization \\ Engineers, Karshi, Uzbekistan
}

\begin{abstract}
To improve the quality and energy indicators on the front plow in front of the housings, the angle axes are installed in the form of a triangular wedge. The purpose of the study is to substantiate the parameters of the angle-lift of the front plow, which provides high-quality performance of the technological process according to agrotechnical requirements with the lowest energy costs for smooth, rowless plowing. The research uses the laws and rules of theoretical mechanics, mathematical statistics, mathematical planning of experiments, and methods of strain measurement, as well as the methods given in existing regulatory documents. Based on the study of the process of interaction of the carbon monoxide with the soil, analytical dependences are obtained that allow us to determine the parameters of the carbon monoxide. According to the results of theoretical and experimental studies, it was found that the required quality of tillage with a front plow following the established agrotechnical requirements with minimal energy consumption is provided at the height of $22 \mathrm{~cm}$, a length of $27 \mathrm{~cm}$, a wing angle of $32^{\circ}$ and an angle of inclination of the side face of $36^{\circ}$.
\end{abstract}

\section{Introduction}

Agriculture is the main branch of the economy of our republic. In this regard, research works are being conducted aimed at developing new scientific and technical bases of resource-saving technologies for tillage [1-23], sowing [6, 13], harvesting [2, 9-10, 18-19], and processing [21-22] of grain and re-crops products and technical means for their implementation. It is known that the use of smooth plowing technology in the main tillage of the soil allows eliminating the disadvantages of the widely used traditional plowing with the turnover of layers in the adjacent. The use of plows for smooth plowing makes it

\footnotetext{
* Corresponding author: sherzod.020508@mail.ru
} 
possible to eliminate high irrational costs for carrying out additional passes of the unit for leveling the pile ridges and collapse furrows, to abandon the costs associated with the division of the field into corrals, to improve the working conditions of agricultural machinery in subsequent operations. At the same time, the volume of annual planning work can be reduced by $30 \%$ or more [38-40].

In this direction, particularly the development of ploughs for smooth, rowless plowing and the justification of the technological process of their working bodies, ensuring resource conservation in the processes of their interaction with the soil is relevant.

V.Sakun [24, 31, 33], V.Sharov [32], Ya.Lobachevsky [26-33], S.Zolotarev [25], L.Kaufman [37], D. Totten [37], F.Mamatov [1-23], I.Ergashev were engaged in the development and improvement of ploughs for smooth, rowless plowing and research to substantiate the parameters of their working bodies[1, 5, 11, 23, 27], N.Aldoshin [2, 9, 10, 18, 19], H.Ravshanov [3, 4, 5, 19] and others.

The purpose of the study is to substantiate the parameters of the angle-lift of the front plow, which provides high-quality performance of the technological process according to agrotechnical requirements with the lowest energy costs for smooth, rowless plowing.

\section{Method}

The research uses the laws and rules of theoretical mechanics, mathematical statistics, mathematical planning of experiments, and methods of strain measurement and the methods given in existing regulatory documents [41-42]..

The angle brackets 3 , made in the form of a triangular wedge, are installed in front of the body 4 with the butt plates 5 [33-35]. In the process of operation, the angle-pickers 3 cut off the upper corner of the formation and wrap it around it. In this case, a polygonal formation is formed; thus, the rotation of the formation by $180^{\circ}$ into its own furrow is facilitated under the combined influence of the body 4 and the plow 5 .

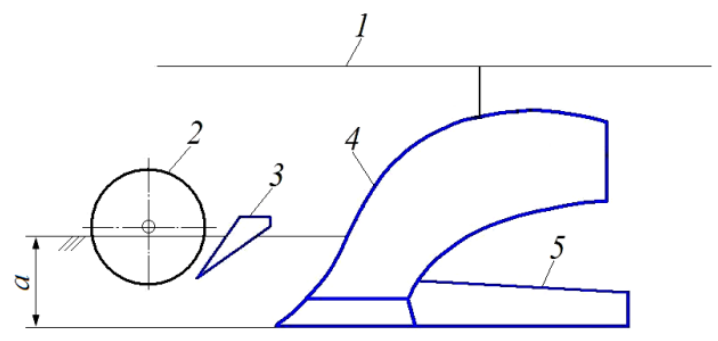

Fig. 1. Diagram of the front plow: 1 is frame; 2 is disc knife; 3 is angle-lift; 4 is body; 5 is plowshare

The main parameters that affect the work process of the angle grinder include the angle of entry of the front edge of the cutter into the ground $\alpha_{b}$, the angle of rotation of the angle cutter $\beta_{b}$, the angle of inclination of the side edge of the cutter $\delta_{b}$, the opening angle of the angle grinder $\gamma_{b}$, the angle of inclination $l_{b}$ of the working edge $N_{b}$ (Fig.2). 


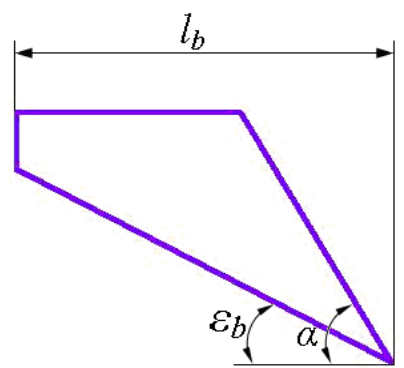

a)

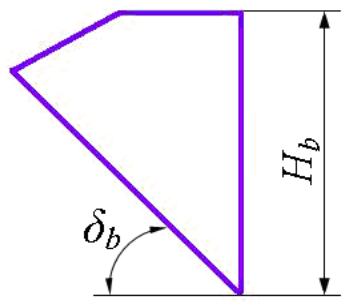

b)

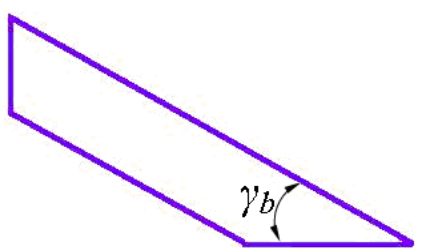

c)

Fig. 2. The main parameters of the image capture: $a$ - side view; $b$ - front view; $c$ - top view

During the operation of the angle cutter (Fig.2), a small triangular plate $A B C$ with width $\mathrm{bb}$ and height a / 2 should be cut from the edge of the $A E K M$ rectangular plate and placed on top of the $A E K M$ plate. To do this, the initially cut $A B C$ blade rises to a certain $h_{2}$ height along the $B S$ edge. The ascent process continues until the center of gravity of the $A B C$ plate falls on a vertical line passing through the $B$ edge. The pallet then begins to rotate around point $A B C B$. Under the action of the angle cutter, the $A B C$ plate is pushed to the side as it rotates around $B$, and the $A E K M$ is placed on top of the plate.

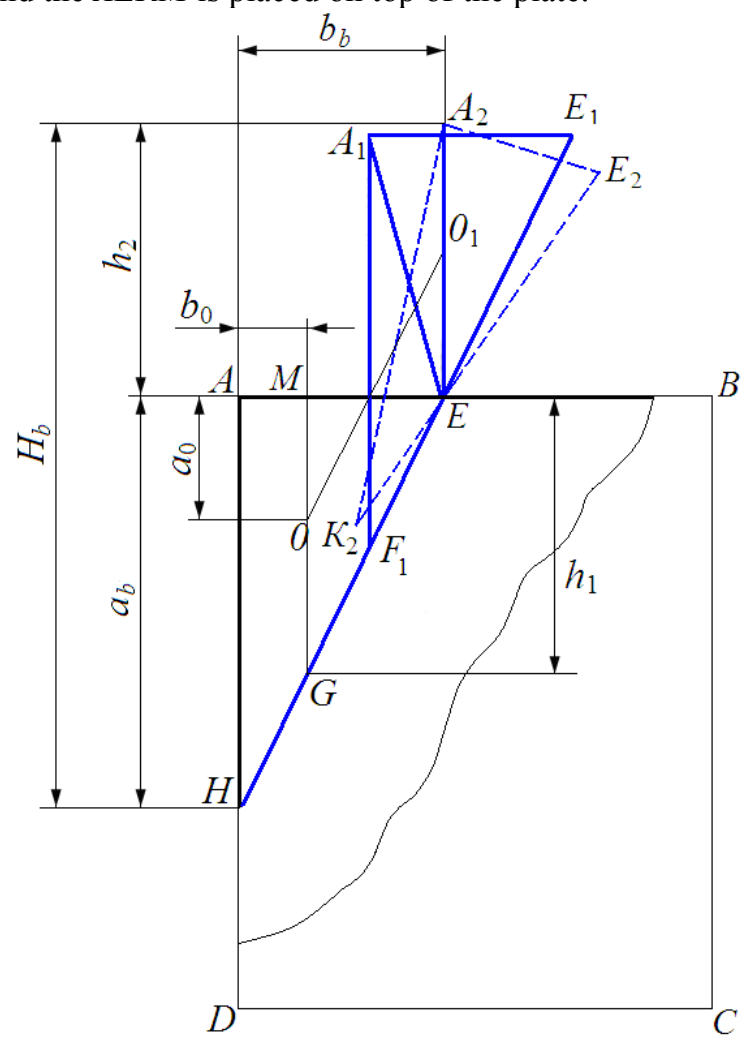

Fig. 3. Scheme for determining the height of the reservoir lift under the action of the angle lift

Based on the scheme shown in Figure 3, we determine the maximum lift height of the slab cut with an angle cutter. Basically 


$$
\begin{aligned}
H_{b}=A C+A_{2} B & =a_{b}+h^{2}, \\
A_{2} B & =A_{1} B=h_{2},
\end{aligned}
$$

$A_{1} A_{2} E$ from the triangle

$$
A_{2} B=h_{2}=\sqrt{b_{0}^{2}+h_{1}^{2}} .
$$

In this case, bo is the triangle $A B C$, i.e., the coordinate of the center of gravity of the crosssection of the plate cut by the angle cutter.

$A B C$ triangle

$$
b_{0}=\frac{1}{3} b_{b}
$$

From the similarity of $A E K$ and $M E L$ triangles

$$
h_{1}=\frac{a_{b}\left(b_{b}-b_{0}\right)}{b_{b}} .
$$

$h_{1}$, and we can set the values of $b_{0}$ to (2) according to (3)

$$
h_{2}=\frac{1}{3} \sqrt{b_{b}^{2}+4 a_{b}^{2}}
$$

Substituting the values of $h_{2}$ and $b_{0}$ on (4) to (1), we obtain the following final expression to determine the maximum elevation of the slab cut with an angle cutter.

$$
H_{b}=a_{b}+\frac{1}{3} \sqrt{b_{b}^{2}+4 a_{b}^{2}}
$$

According to expression (6), when $a_{b}=12 \mathrm{~cm}$ and $b_{b}=8-10 \mathrm{~cm}$, the height of the angle cutter is in the range $N_{b}=21.24-21.48 \mathrm{~cm}$. We take it $22 \mathrm{~cm}$.

We determine the length of the angle cutter using Figure 4. Basically

$$
l_{b}=O A=H_{b} \operatorname{ctg} \alpha_{b} .
$$

We can set the value of $H_{b}$ to (8) according to (7)

$$
l_{b}=\left(\alpha_{b}+\frac{1}{3} \sqrt{b_{b}^{2}+4 a_{b}^{2}}\right) \operatorname{ctg} \alpha_{b}
$$

According to expression (8), when $a_{b}=50^{\circ}, a_{b}=12 \mathrm{~cm}$ and $b_{b}=8-10 \mathrm{~cm}$, the length of the angle cutter is in the range of $l_{b}=25.3-26.6 \mathrm{~cm}$. We accept it $27 \mathrm{~cm}$. 


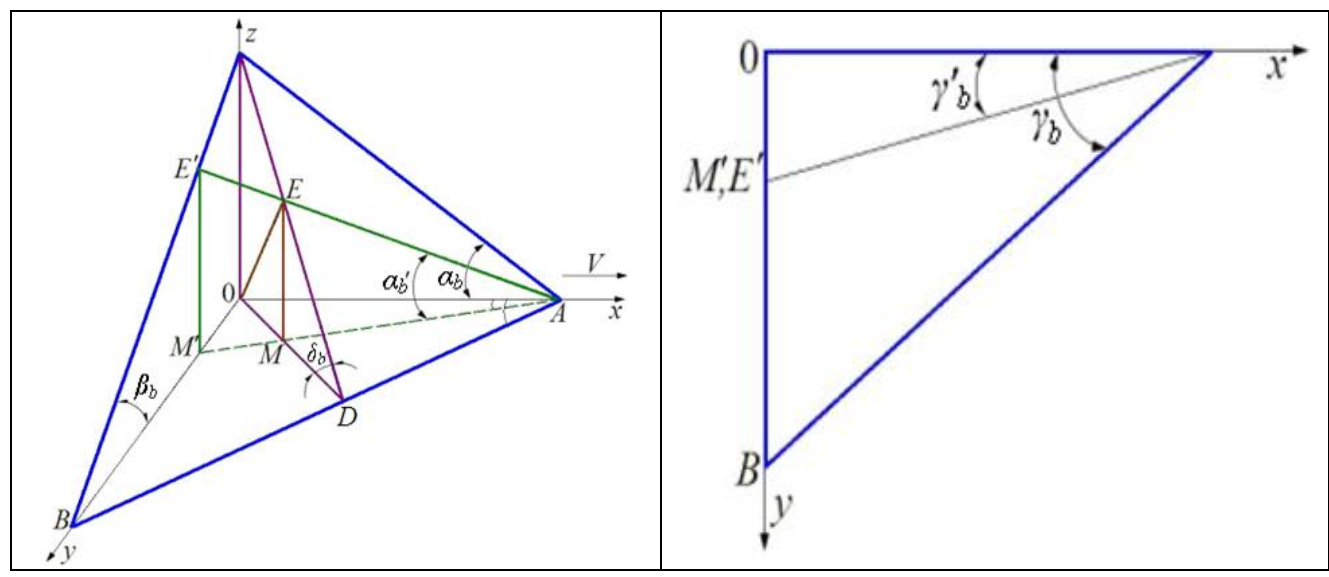

Fig. 4. To determine the length of the angle pickup

\section{Results and Discussions}

To conduct experiments to justify the width of the capture and the depth of processing of the angle image, a laboratory and field installation was developed. Experimental studies were conducted in two stages. In the first stage, we studied the influence of the angle of the side faces and the depth of aglaonema and operating speed on the quality and the tractive resistance of aglaonema. At the second stage, multivariate experiments were carried out using mathematical planning of experiments. The experiments were carried out in the grain fields of the experimental area of the Research Institute of Mechanization and Electrification of Agriculture (IMESH).

The angle of inclination of the side edge of the angle grinder is one of the main parameters that affect its performance. Therefore, experimental studies were conducted to determine its optimal value. The study results showed that as a result of the angle of inclination of the side edge of the angle grinder, the distance to throw the soil to the side at both operating speeds increased according to the law of concave parabola (Fig. 5a). This can be explained by an increase in the volume of soil cut with an angle cutter. It is known that as the angle of inclination of the side edge of the angle cutter increases, its coverage width also increases. Increasing the coverage width leads to an increase in soil volume.
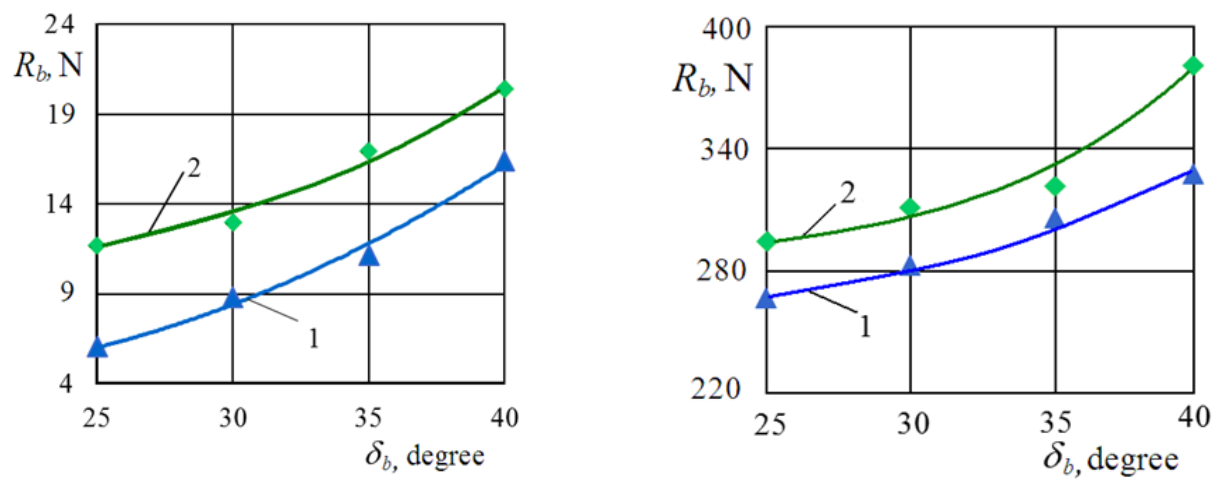

Fig. 5. Graphs of the dependence of the distance of the soil spread $(S)$ and the traction resistance of the slope $(R)$ from the angle of inclination of the side face of the slope: $\left(\delta_{b}\right)$ : operating speed 1 and $2(6.5$ and $8.5 \mathrm{~km} / \mathrm{h})$, respectively 


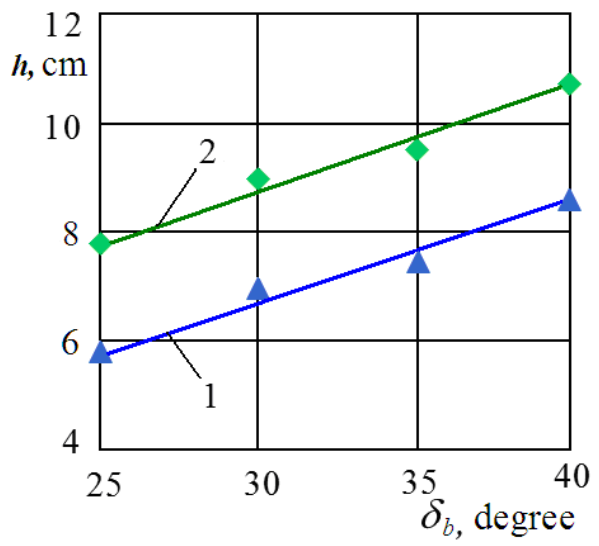

Fig. 6. Graphs of the dependence of the height of the ridge $(h)$ on the angle of inclination of the side face of the angle pickup $\left(\delta_{b}\right): 1$ and 2, respectively, at a speed of movement $(6.5$ and $8.5 \mathrm{~km} / \mathrm{h}$ )

In the next stage of the experiments, the effect of the angle cutter's gravitational resistance on increasing the angle of inclination of the cutting edge was studied (Fig.5b), and the results showed that the gravitational resistance of the rectangular cutter increased at both operating speeds according to the concave parabola law. In this case, the angle cutter operates in a closed zone on the surface of the uncultivated field in the footsteps of a disc blade. Of course, as the angle of inclination of the side edge increases, the coverage width of the angle cutter increases. This, in turn, leads to increased resistance to gravity.

According to a one-factor experiment found that when the speed of the front plow 6,5$8,5 \mathrm{~km} / \mathrm{h}$ to ensure the required quality of work with minimum expenditure of energy, the angle of the working edge of aglaonema should be $36^{\circ}$, the depth of cut and width of aglaonema respectively 12.5 and $10 \mathrm{~cm}$.

The multivariate experiments were conducted according to the Hartley- 4 plan. At the same time, the longitudinal distance between the angle bracket and the body $\left(X_{1}\right)$, the width of the angle bracket $\left(X_{2}\right)$, and the speed of the unit $\left(X_{3}\right)$ were chosen as the main factors.

When conducting a multivariate experiment, the degree of soil crumbling, that is, fractions of at least $50 \mathrm{~mm}$ in $\operatorname{size}\left(Y_{1}\right)$ and the traction resistance $\left(Y_{2}\right)$ of the angle lift, were taken as evaluation criteria.

Based on the results of experimental studies, regression equations are obtained that adequately describe the evaluation criteria:

- according to the degree of soil crumbling, \%;

$$
\begin{array}{r}
Y_{1}=+85.533+1.427 X_{1}+1.183 X_{2}+2.090 X_{3}-6.067 X_{1}^{2}- \\
-0.367 X_{1} X_{3}-1.317 X_{2}^{2}-1.108 X_{2} X_{3}-1.517 X_{3}^{2}
\end{array}
$$

- according to the traction resistance of the angle-lift, N;

$$
\begin{aligned}
& Y_{2}=+358.834-16.550 X_{1}-3.983 X_{2}+10.233 X_{3}+20.750 X_{1}^{2}- \\
& -2.800 X_{1} X_{2}-2.817 X_{1} X_{3}+53.550 X_{2}^{2}+9.266 X_{3}^{2} .
\end{aligned}
$$

The analysis of the obtained regression equations showed that all factors significantly impacted the evaluation criteria. The regression equations were solved using the MSExcel and PLANEX programs from the conditions that the criterion $Y_{1}$, i.e., the amount of fraction with a size of at least $50 \mathrm{~mm}$, should be at least $80 \%$, and the criterion $Y_{2}$, i.e., the 
traction resistance of the angle pickup should be the minimum value.

According to the results obtained when the speed of the front plow with $6,5-8.5 \mathrm{~km} / \mathrm{h}$ to ensure the required quality of work with minimum energy consumption when the depth of processing of aglaonema 12.0-12.5 $\mathrm{cm}$, the angle of the working edge of aglaonema in the range of $36^{\circ}$. The results obtained correspond to the results of theoretical studies.

\section{Conclusions}

Based on the study of the process of interaction of the carbon monoxide with the soil, analytical dependences are obtained to determine the parameters of the carbon monoxide.

By results of the conducted researches, it is established that the required quality of the soil with a plow in front accordance with agrotechnical requirements at a minimum cost of energy is achieved when the height of aglaonema $22 \mathrm{~cm}$, length $27 \mathrm{~cm}$, angle wing solution $32^{\circ}$ and the angle of inclination of the side faces $36^{\circ}$.

\section{References}

1. Mamatov, F., Ergashev, I., Ochilov, S., Pardaev, X. Traction Resistance of Soil Submersibility Type "Paraplau" // Jour of Adv Research in Dynamical \& Control Systems, Vol.12, 07-Special Issue, (2020).

2. Aldoshin, N., Mamatov, F., Ismailov, I., Ergashov, G. Development of combined tillage tool for melon cultivation // 19th international scientific conference engineering for rural development Proceedings, Jelgava, 20.-22.05.2020. Volume 19.

3. Umurzakov, U., Mirzaev, B., Mamatov, F., Ravshanov, H., Kurbonov, S. A rationale of broach-plow's parameters of the ridge-stepped ploughing of slopes // XII International Scientific Conference on Agricultural Machinery Industry IOP Conf. Series: Earth and Environmental Science 403(2019) 012163

4. Mirzaev, B., Mamatov, F., Chuyanov, D., Ravshanov, X., Shodmonov, G., Tavashov, R and Fayzullayev, X. Combined machine for preparing soil for cropping of melons and gourds // XII International Scientific Conference on Agricultural Machinery Industry. doi.org/10.1088/1755-1315/403/1/012158.

5. Mirzaev, B., Mamatov, F., Ergashev, I., Ravshanov, H., Mirzaxodjaev, Sh., Kurbanov, Sh., Kodirov, U and Ergashev, G. Effect of fragmentation and pacing at spot ploughing on dry soils, E3S Web of Conferences 97. doi.org/10.1051/e3sconf/201913501065.

6. Mamatov, F., Mirzaev, B., Shoumarova, M., Berdimuratov, P., Khodzhaev, D. Comb former parameters for a cotton seeder, International Journal of Engineering and Advanced Technology (IJEAT) Volume-9 Issue 1

7. Mamatov, F., Mirzaev, B., Batirov, Z., Toshtemirov, S., Tursunov, O., Bobojonov, L. Justification of machine parameters for ridge forming with simultaneous application of fertilizers, IOP Conf. Series: Materials Science and Engineering 883(2020)

8. Mirzaev, B., Mamatov, F., Avazov, I., Mardonov, S. Technologies and technical means for anti-erosion differentiated soil treatment system // E3S Web of Conferences. doi.org/10.1051/e3sconf/20199705036.

9. Aldoshin, N., Didmanidze, O., Mirzayev, B., Mamatov, F. Harvesting of mixed crops by axial rotary combines // Proceeding of $7^{\text {th }}$ International Conference on Trends in Agricultural Engineering 2019. 17 $7^{\text {th }}-20^{\text {th }}$ Prague, Czech Republic. pp. 20-26, September (2019).

10. Mirzaev, B., Mamatov, F., Aldoshin, N and Amonov, M. Anti-erosion two-stage tillage by ripper// Proceeding of 7th International Conference on Trends in Agricultural Engineering 17th-20th. Prague, Czech Republic. pp.391-396, (2019) 
11. Mirzaev, B., Mamatov, F., Ergashev, I., Islomov, Yo., Toshtemirov, B., Tursunov O. Restoring degraded rangelands in Uzbekistan, Procedia Environmental Science, № 6. - pp 395-404. (2019).

12. Uzakov, Z.U., Mamatov, F.M., Begulov, O. Implementation of object-oriented Programming technology in the one-dimensional oil displacement problem, International Conference on information Science and Communications Technologies: ICISCT 2019/0012008. Tashkent, Uzbekistan

13. Mamatov, F., Mirzaev, B., Berdimuratov, P., Turkmenov, Kh., Muratov, L., Eshchanova, G. The stability stroke of cotton seeder moulder (2020). IOP Conf. Series: Materials Science and Engineering 883 (2020) 012145

14. Mamatov, F., Mirzaev, B., Tursunov, O. A Justification of Broach-Plow's Parameters of the Ridge-Stepped Ploughing // E3S Web of Conferences 97, 05035 (2019). doi.org/10.1051/e3sconf/20199705035.

15. Ahmedov, B.J., Mirzaev, B.S.,Mamatov, F.M., Khodzhaev, D.A., Julliev, M.K. Integrating of gis and gps for ionospheric perturbations in d-And f-layers using vlf receiver // InterCarto, InterGIS 26, -pp. 547-560. DOI: 10.35595/2414-9179-2020-126-547-560.

16. Mamatov, F., Mirzaev, B., Tursunov, O., Ochilov, S and Chorieva, D. Relief, physicomechanical and technological properties of soil in the cotton growing area // ICECAE 2020. IOP Conf. Series: Earth and Environmental Science 614(2020) 012169. IOP Publishing. doi:10.1088/1755-1315/614/1/012169.

17. Shamsutdinov, Z., Ubaydullaev, Sh., Shamsutdinov, N., Mirzaev, B., Mamatov, F., and Chorshabiyev, N. The concept of the phytogenic field: theory, research experience and practical significance, ICECAE 2020. IOP Conf. Series: Earth and Environmental Science 614(2020) 012164. IOP Publishing. doi:10.1088/1755-1315/614/1/012164.

18. Umurzakov, U., Mamatov, F., Aldoshin, N., and Mirzaev, B. Exploration of tillage technologies in the Republic of Uzbekistan // ICECAE 2020 IOP Conf. Series: Earth and Environmental Science 614(2020) 012168. IOP Publishing. doi:10.1088/17551315/614/1/012168.

19. Mamatov, F., Aldoshin, N., Mirzaev, B., Ravshanov, H., Kurbanov, Sh and Rashidov, N. Development of a frontal plow for smooth, furless plowing with cutoffs // IPICSE 2020. IOP Conf. Series: Materials Science and Engineering 1030 (2021) 012135 IOP Publishing. doi:10.1088/1757-899X/1030/1/012135.

20. Mamatov, F., Mirzaev, B., Mirzahodzhaev, Sh., Uzakov, Z and Choriyeva, D. Development of a front plow with active and passive working bodies // IPICSE 2020. IOP Conf. Series: Materials Science and Engineering 1030 (2021) 012164. IOP Publishing. doi:10.1088/1757-899X/1030/1/012164.

21. Mamato, F.M., Eshdavlatov, E., Suyuno, A. Continuous Feed Mixer Performance //Journal of Advanced Research in Dynamical and Control Systems (JARDCS). Volume-12, 07-Spesia1 Issue, 2020. DOI: 10.5373/JARDCS/V12SP7/20202343. ISSN 1943-023X.

22. Mamatov, F.M., Eshdavlatov, E., Suyunov, A. The Shape of the Mixing Chamber of the Continuous Mixer // Jour of Adv Research in Dynamical \& Control Systems, Vol. 12, 07-Special Issue, 2020. DOI: 10.5373/JARDCS/V12SP7/20202318 ISSN 1943$023 \mathrm{X}$.

23. Mamatov, F., Ergashev, I., Mirzaev, B., Pardaev, X, Chorieva, D. Research of the Penetration Process of the Frontal Plow // 2nd Bukittinggi International Conference on Education (BICED) 2020. Journal of Physics: Conference Series 1779 (2021) 012002. IOP Publishing. doi:10.1088/1742-6596/1779/1/012002.

24. Sackun V.A, Lobachevsky Y.P., Sizov O.A., Sharov V.V. New Technology and Eguipment for Level Ploughing Silsoe Research Institute. Translation. - №34. 
Silsoe,--pp.1-7. England, (1991).

25. Zolotarev S.A. Obosnovanie tehnologicheskogo processa i parametrov pluga dlja gladkoj vspashki: Diss. ... kand. teh. nauk. - Moskva: MGAU,-p. 225. (2005).

26. Lobachevskij Ja.P. Tehnologii i tehnicheskie sredstva dlja gladko jvspashki. Moskva: MGAU,- p. 99. (2001).

27. Lobachevskij Ja.P., Mamatov F.M., Jergashev I.T. Frontal'nyj plug dlja hlopkovodstva// Hlopok. - 1991. - №6. - S. 35-37. (In Russian)

28. Lobachevskij Ja.P. Semejstvo frontal'nyh plugov dlja gladkoj vspashki: Dis. ... dok. teh. nauk. - Moskva: MGAU, 2000. - 335 c. (In Russian)

29. LobachevskyY.P. New concept to fploughing: Technology and Equipment. Agricultural Equipment Technology Conference" AET C1997". Paper №97-AET C103. Louisville, Kentucky. - USA, 1997. - P.1-10. (In Russian)

30. LobachevskyY.P. New technology of the flat ploughing and design of the frontploughs. A n ASA E Meeting Presentation. Paper № 961071. Phoenix, Arizona, USA, 1996. - P.1-8. (In Russian)

31. Sakun V.A., Lobatchewsky Y.P. Lang fristigetrends in derentwicklungvonbodenbearbeitungsgeraten. Agrar technisch eberichte. Institut furAgrartechni kund Universität Hohenheim. - Stuttgart,1993. - P.76-82. (In Russian)

32. Sharov V.V. Obosnovanie osnovny hparametrov rotornogo pluga dljagladkoj vspashki: Diss. ... kand. teh. nauk. - M.: - 227. (1986).

33. Sizov O.A., LobachevskijJa.P., Sakun V.A. Sovremennyjjetap i putidal'nejshegorazvitij apahotny hagregatov // Tehnika v sel'skomhozjajstve. - №3. 0.9-12. (1991).

34. Sizov O.A., Mamedova L.V., Bliev A.A. Tehnologicheskie i konstruktivnye osobennosti perspektivny hplugov dlja gladko jvspashki i novyj metod ocenkie ejeffektivnosti. Sb. nauch. trudov, t.120. - M.: VIM. - p.231. (1989).

35. ShpakovskijN.A. Intensifikacij aprocessa obrabotki pochvy na osnoveprimenenij a frontal'nogo pluga. Diss.... kan.teh. nauk. - M., -p. 186. (1991).

36. A.S. 470258. Frontal'nyjplug/ Mil'cev A.I., Kirjuhin V.G., Korotkov V.S., Moskvicheva V.D. // B.I.- № 18. - (1975).

37. Kaufman L.C., Totten D.S. Development of an inverting moldboard plow // Trens ASAE,- №1. - pp.50-58. (1972).

38. Donald K. Shannon Precision Agriculture, Wil lit Work An Extension Deminstruction Project. - Emerging Technologies for $21^{\text {st }}$ century, ASAE/CSAE, - p № 99. 1140. 335. (1999).

39. Nichols M. Method of research in soil dynamic a sapplied to implement design.Auburn, - p.229. (1929).

40. Robert J. Monson. The Application of Enhanced GPS Systems for Navigation in Precision Agriculture. - Managing today's technology, ASAE,- p. № 961023. (1996).

41. Fayzullayev Kh, Mamatov S, Radjabov M, Sharipov Sh, Tavashov R and Nurmanova, $\mathrm{M}$. The quality of loosening the soil with subsoilers of the combined machine, IOP Conf. Series: Materials Science and Engineering 1030 (2021)

42. Temirov I, Ravshanov Kh Fayzullaev Kh, Ubaydullaev Sh and Kodirov U. Development of a machine for preparing the soil for sowing melons under the film, IOP Conf. Series: Materials Science and Engineering 1030 (2021) 